Sedimentary

Research
Journal of Sedimentary Research, 2009, v. 79, 302-315

Research Article

DOI: $10.2110 /$ jsr.2009.028

\title{
HIGH-FREQUENCY RHYTHMICITY IN A MIXED SILICICLASTIC-CARBONATE SHELF (LATE MIOCENE, GUADIX BASIN, SPAIN): A MODEL OF INTERPLAY BETWEEN CLIMATIC OSCILLATIONS, SUBSIDENCE, AND SEDIMENT DISPERSAL
}

\author{
FERNANDO GARCÍA-GARCÍA, ${ }^{1}$ JESÚS M. SORIA, ${ }^{2}$ CÉSAR VISERAS,${ }^{3}$ AND JUAN FERNÁNDEZ ${ }^{3}$ \\ ${ }^{1}$ Departamento de Geología, Universidad de Jaén, Campus de Las Lagunillas s/n, 23071 Jaén, Spain \\ ${ }^{2}$ Departamento de Ciencias de la Tierra, Universidad de Alicante, Apartado Correos 99, 03080 Alicante, Spain \\ ${ }^{3}$ Departamento de Estratigrafia y Paleontología, Universidad de Granada, Campus de Fuentenueva s/n, 18071 Granada, Spain \\ e-mail: fegarcia@ujaen.es
}

\begin{abstract}
Rhythmites in pelagic sediments can include information on paleoclimate and with orbital cycles. This paper documents and interprets an unusual rhythmic succession from a cool-water shallow-marine shelf that includes features of Mediterranean-type ramps and open-ocean-type ramps. In the subsiding southwestern margin of the Guadix Basin (southern Spain, Betic Cordillera), during the late Tortonian, a 640-m-thick succession was deposited over a short period (7.8-7.2 Ma). This succession contains 30 sedimentary packages or rhythmites, each defined by two facies associations: a mixed crossstratified siliciclastic-skeletal sandstone and a homogeneous marl rich in planktonic foraminifera. Sandstones ranging in thickness from $3 \mathrm{~m}$ to $20 \mathrm{~m}$ contain coralline algae, bivalves, bryozoans, benthic foraminifera, echinoids, and brachiopods (typical temperate-water shelf biofacies). These units exhibit cross-strata sets up to four meters high, interpreted to have been produced by strong unidirectional currents. The marly deposits range in thickness from 2 to $17 \mathrm{~m}$ and contain an association of cold-water planktonic foraminifera as well as thin sandstone layers that exhibit normal grading corresponding to typical incomplete Bouma sequences or a lower division with planar lamination and an upper division of very fine- to fine-grained sandstone with hummocky and swaly cross-stratification. On the basis of the sedimentary structures, the sandstone layers are interpreted as sporadic turbidity flows and storm ebb-surge deposits.

On the basis of the sedimentary structures, the hydrodynamic conditions during deposition of the mixed siliciclasticcarbonate interval were high-energy. Based on sedimentary and biogenic features of the rhythmites and their temporal durations (ca. $20 \mathrm{ka}$ ), rhythmicity is interpreted to reflect alternating cool-wet and cold-dry climate episodes driven by precession orbital cycles. This occurrence of alternating mixed carbonate-siliciclastic sedimentation and pelagic sediments represents a unique occurrence in the geologic record.
\end{abstract}

\section{INTRODUCTION}

During the late Miocene, changes in climate and sea level drove different types of rhythmic sedimentation in different depositional environments. During this time period, rhythmic sediments have been described in environments such as deep marine basins with predominately pelagic sedimentation (Sierro et al. 1999; Krijgsman et al. 2001), carbonate shelves (Brachert et al. 1996), deltas (García-García et al. 2006a, 2006b; Soria et al. 2000), fringing reefs (Braga and Martín 1996), siliciclastic coasts (Roep et al. 1998), and shallow marine evaporites (Michalzik 1996). The paleoclimatic meaning of rhythmites and their relation with orbital cycles has been a focus of renewed interest, especially in pelagic sediments. In these systems, sediments commonly show alternations of homogeneous marls and sapropelites, which have been interpreted to reflect precession-related changes in climate (Hilgen et al. 1995; Nijenhuis 1999; Sierro et al. 1999; Vázquez et al. 2000; Krijgsman et al. 2001), with the homogeneous marls representing cold and subarid periods, and the sapropelites reflecting temperate and humid conditions (Vázquez et al. 2000).

This work documents an unusual set of sedimentary rhythmites generated on a shallow-marine shelf, in a system where pelagic deposition alternated with mixed carbonate-siliciclastic sedimentation. Our study focuses on interpreting the genesis and features of the rhythmic succession Although cool-water carbonate deposition is often controlled by relatively short-term eustatic changes (Hansen 1999; Tesson et al. 2000), following Pedley and Carannante (2006) we propose as an alternative that the ramp rhythmicity can be controlled by short-period catastrophic changes in climate. Whereas eustasy is the main regulator, climate and oceanography determine terrigenous clastic sediment supply and carbonate productivity and thus the character of the sedimentary deposits (Lukasik and James 2006). It is less apparent how climate affects the nature of a non-tropical than tropical depositional system (Lukasik and James 2006). This study reveals that climatic signatures documented in deep-marine deposits from the eastern Mediterranean (Postma and Drinia 1993; Postma et al. 1993) which point to precession-punctuated variation in discharges in the late Miocene can be recognized in non-tropical shallow marine deposits from the western Mediterranean during the late Tortonian.

GEOLOGICAL SETTING AND GENERAL STRATIGRAPHY OF THE GUADIX BASIN

The Guadix Basin is located in the central sector of the Betic Cordillera in the southern Iberian Peninsula (Fig. 1A). It is an intermontane basin 

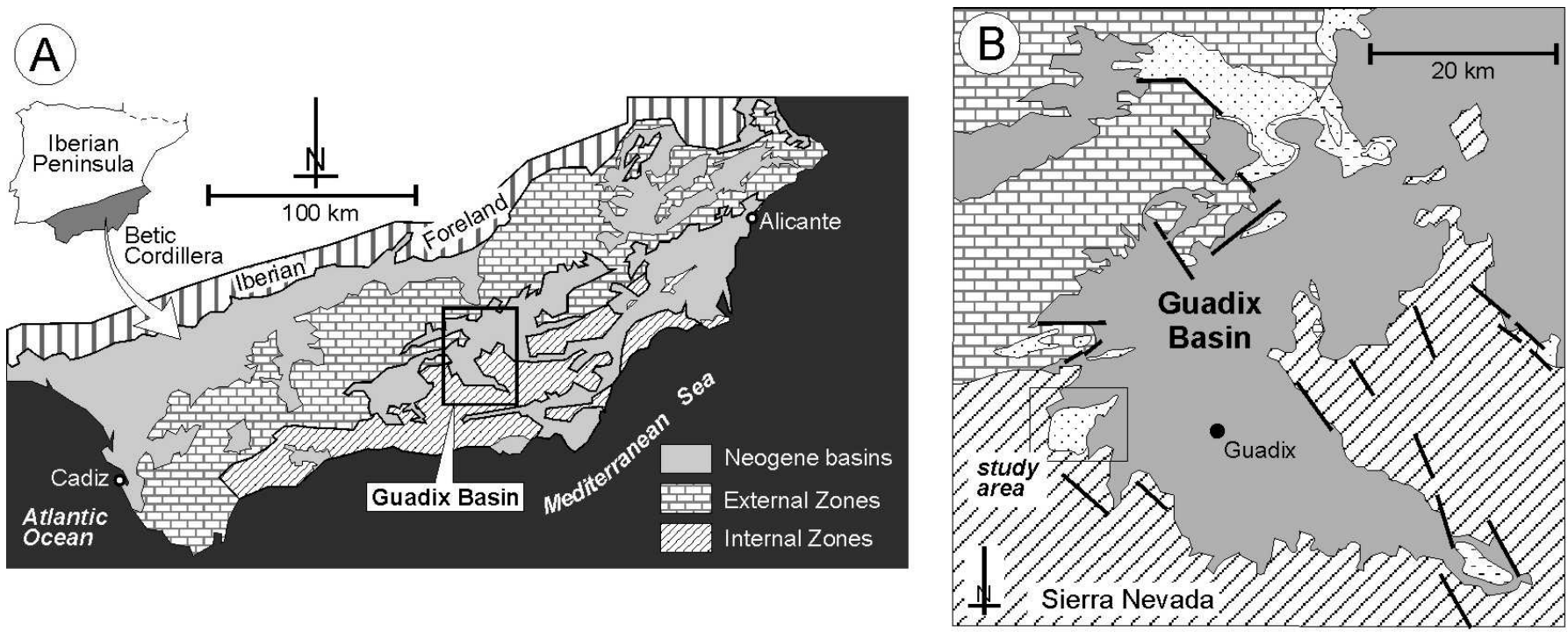

Basement

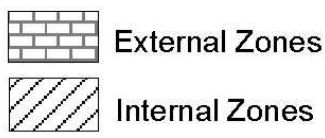

Guadix Basin

Pliocene and Quaternary

late Miocene (continental)

late Miocene (marine)

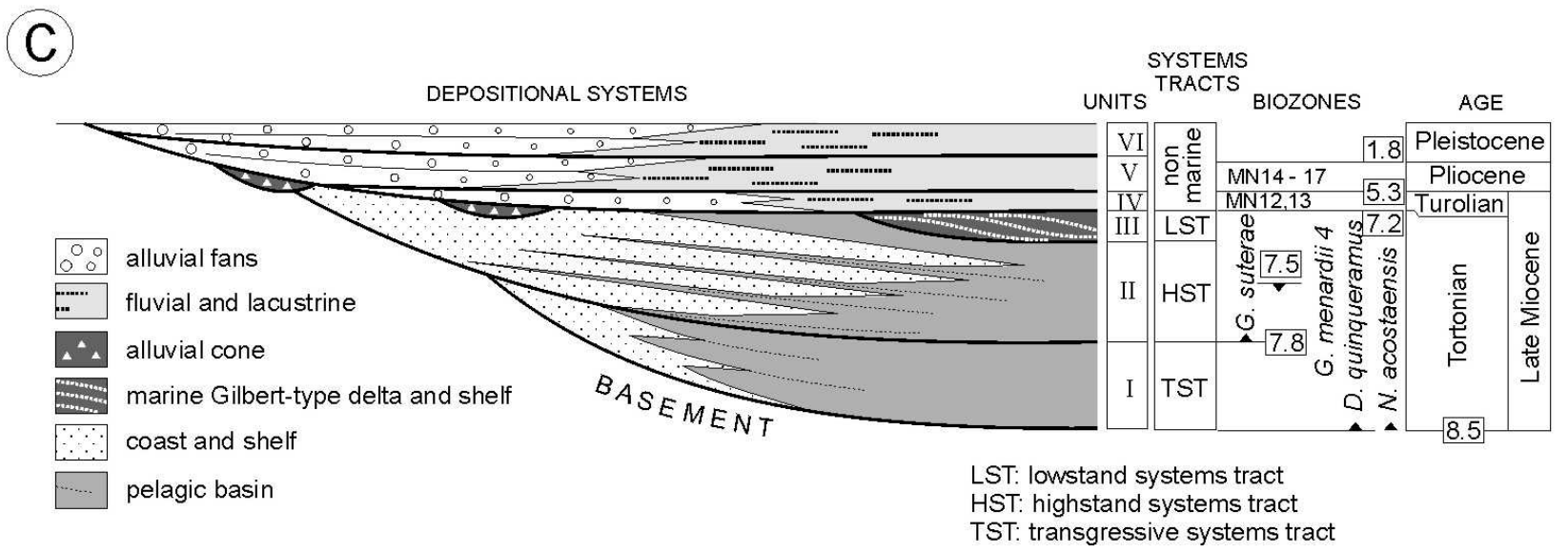

FIG. 1.-A) Location of the Guadix Basin in the Betic Cordillera. B) Geological map of the Guadix Basin showing location of the study area. C) Stratigraphic architecture and biostratigraphy of the Guadix Basin.

formed during the late Miocene after the main movements of orogenic structuring of the cordillera (Sanz de Galdeano and Vera 1992; Viseras et al. 2004). The sedimentary infill overlies the contact between the two principal geological domains of the Betic Cordillera: the Internal Zones and the External Zones (Fig. 1B). The Internal Zones are dominantly Paleozoic and Triassic metamorphic rocks that form the basement of the southern half of the basin; the External Zones are mainly Mesozoic sedimentary rocks that constitute the basement of the northern half of the basin. Tectonically, the Guadix Basin exhibits a network of extensional faults, primarily trending NW-SE. These faults have been active from the late Miocene to the Quaternary and have controlled subsidence within the basin and the uplift of the surrounding highlands (Soria et al. 1998, 1999; Soria et al. 2003). Paleogeographically, during the Miocene, the Guadix Basin was a marine extension of the western Mediterranean that had a link to the Atlantic Ocean (Sanz de Galdeano and Vera 1992; Soria et al. 1999).
The general stratigraphic architecture of the Guadix Basin includes six genetic units (referred to as I-VI, after Fernández et al. 1996). The three lower units represent marine sedimentation during the Tortonian, whereas the upper three units record continental sedimentation from the late Turolian to the Quaternary. Within each genetic unit, several depositional systems, or associations of facies related to certain sedimentary environments, were differentiated. According to the stratigraphic architecture established by Fernández et al. (1996), the three marine units (I, II, and III) represent different sea-level positions in the basin (Fig. 1C). Unit I is represented by two retrogradational systems: coast-shelf skeletal sandstones and pelagic basin marls. Unit II is composed of two progradational systems: coast-shelf mixed siliciclasticskeletal sandstones and pelagic basin marls. Unit III is represented mainly by coarse-grained Gilbert-type deltas, mixed siliciclastic-skeletal sandstones, and coral reefs (Soria et al. 1999; Soria et al 2003). All the 

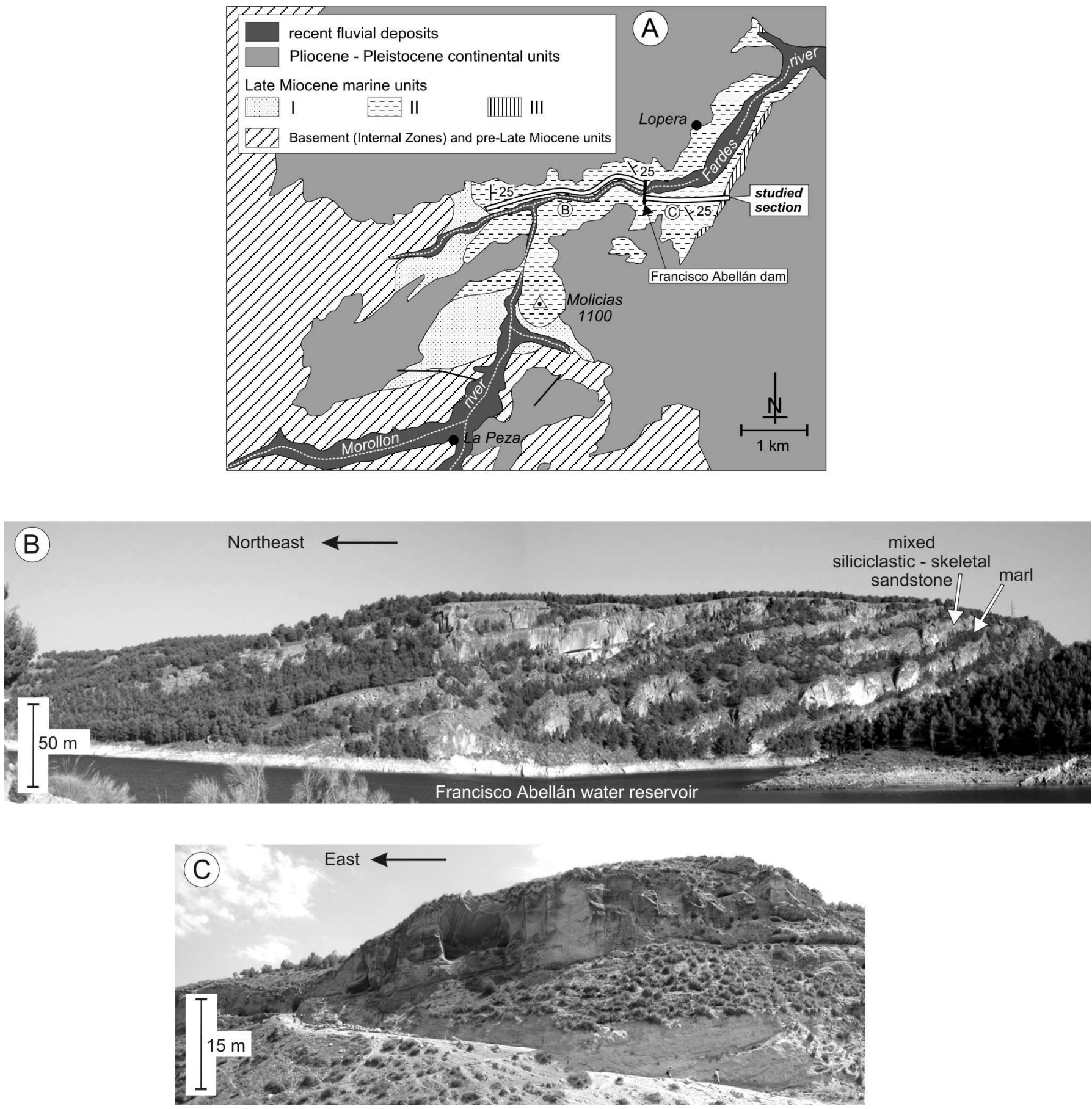

FIG. 2.-A) Geological map of the study area in the southwestern Guadix Basin, with the location of both the studied section as well as panoramic views of parts B and C. B) Stacked rhythmites in the lower and middle parts of the succession. C) Last rhythmite of the succession. Note contrast between the marl interval and the mixed siliciclastic-skeletal sandstones and conglomerates interval.

depositional systems constituting Unit III rest directly over the pelagic basin system of Unit II. Units IV to VI are represented by marginal alluvial fans passing basinward to fluvial and lacustrine deposits.

The age of the three marine units has been established by planktonic foraminifera and calcareous nannoplankton biostratigraphy (Rodríguez Fernández 1982; Soria 1993; Soria et al. 1999). Updating of the previous biostratigraphic data reveals that these three units contain the planktonic foraminifer species Neogloboquadrina acostaensis, which constrains their age to the Tortonian. The presence of the calcareous nannoplankton species Discoaster quinqueramus in the three units further restricts the period of marine sedimentation in the Guadix Basin to the late Tortonian (8.5 Ma minimum, according to Berggren et al. 1995). Unit II is characterized by the first occurrence of the planktonic foraminifer species Globorotalia suterae, a biohorizon situated at 7.8 Ma (Lourens et al. 2004). In the middle part of this unit is the last occurrence of Globorotalia menardii 4 form, dated at 7.5 Ma (Iaccarino and Premoli Silva 2007; for 

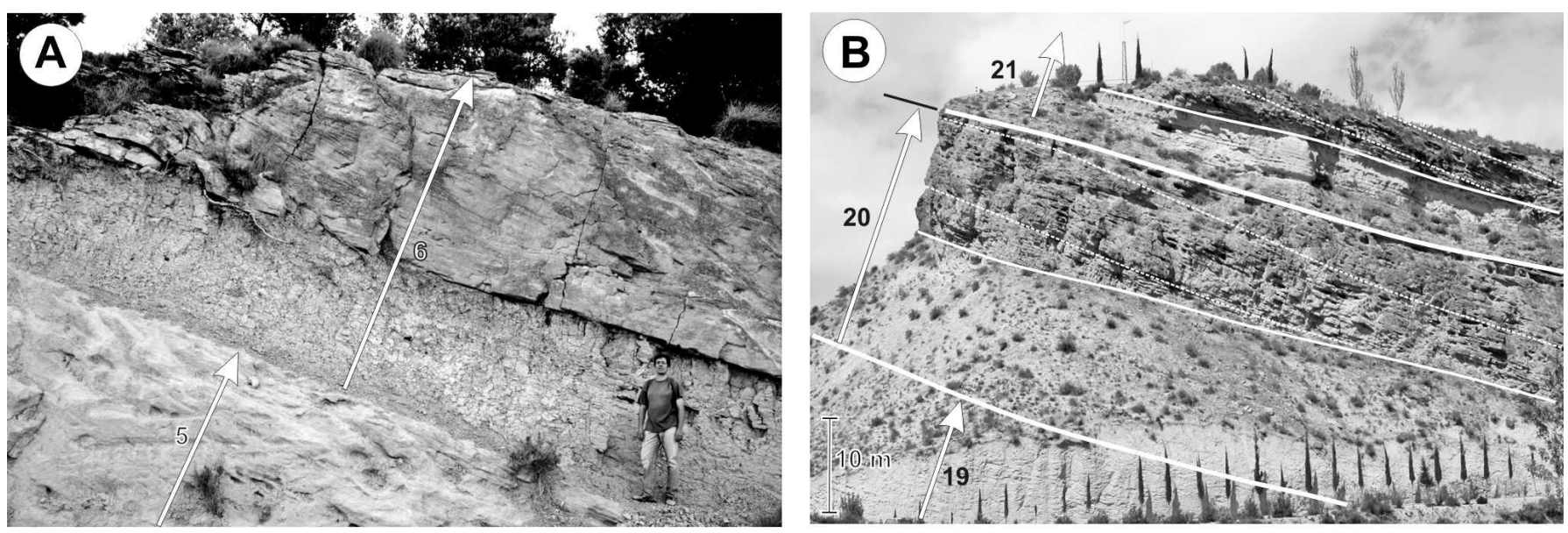

FIG. 3.-A) Detail of rhythmite 6 illustrating the sharp contact between the marl interval and the sandstone interval (person for scale). B) View of rhythmites 20 and 21 , in which the sandstone interval shows prograding clinoforms (dotted line outlines bed geometry).

references). Unit III contains Globorotalia suterae, but without Messinian marker species (Globorotalia conomiozea-Globorotalia mediterranea), and consequently is assigned to the latest Tortonian.

The age of the three continental units has been established fundamentally by rodent biostratigraphy. The lower unit (IV) contains species characteristic of both the MN12 zone (Soria and Ruiz Bustos 1992) and the MN13 zone (Sesé 1989), both biozones from the late Turolian (latest Tortonian-Messinian on the marine scale; Opdyke et al. 1997; Agustí et al. 2001). At the base of Unit IV, the rodent association that characterizes the MN12 zone consists of Ruscinomis schaubi and Occitanomys adroveri (Soria and Ruiz Bustos 1992). These two species also appear at the base of the continental sediments of the neighboring Granada Basin, dated at 7.2 Ma (Rodríguez Fernández and Sanz de Galdeano 2006); we therefore assume the same chronology for the Guadix Basin. The two highest continental units (V and VI) contain numerous rodent and large-mammal sites dated as Pliocene (MN14 to MN17 zones) and Pleistocene (Ruiz Bustos 1990).

\section{STUDY SECTION}

\section{General Features}

The stratigraphic succession studied herein corresponds to Unit II. Both Vera (1968) and Rodríguez Fernández (1982) have reported on the shallow-marine depositional environment and have dated Unit II as Tortonian (late Miocene). The focus area lies in the southwestern sector of the Guadix Basin, at the foot of the Sierra Nevada, between the villages of La Peza and Lopera (Figs. 1B, 2A). This part of the basin has been strongly eroded by the Fardes River, and it is also the site of the Francisco Abellán water reservoir. The succession is tectonically tilted $25^{\circ}$ E-NNE (Fig. 2B, C). The unit is 640 meters thick and includes a rhythmic succession. Each rhythmite consists of two facies associations: marl-dominated and sandstone-dominated associations (Fig. 3). Rhythmite thickness ranges from 5 to 25 meters, and the two lithofacies comprising each rhythmite are always separated by sharp surfaces.

\section{Facies Analysis}

The succession contains 30 rhythmites (Fig. 4). Each package or rhythmite is defined by the alternation of two facies associations: marls with interbedded thin siliciclastic sandstone layers and mixed siliciclasticskeletal cross-stratified sandstone in a tabular geometry (Fig. 3A, B).
Marl Facies Association.-The marl facies are homogeneous marl (ranging in thickness from 2 to $17 \mathrm{~m}$ ) with interbedded thin siliciclastic sandstone layers ranging in thickness from 2 to $50 \mathrm{~cm}$. The marl occurs in massive-bedded strata whose limits are defined by slight changes in color (gray to yellow) or by thin layers of sand (Fig. 5A). Bioturbation is common (Fig. 5B), with Thalassinoides, Ophiomorpha, and Granularia traces (Skolithos ichnofacies) usually produced by endobiont organisms. This marl facies contains abundant planktonic foraminifera, with minor amounts of benthic microfossils such as foraminifera, ostracodes, and siliceous sponge spicules. The dominant planktonic foraminiferal species (over 50\%) is Globigerina bulloides; the remaining most common species are Neogloboquadrina acostaensis, Neogloboquadrina humerosa, Globorotalia suterae, and Globorotalia menardii 4 form.

Thin fine- to coarse-grained sandstone interbeds $(2-50 \mathrm{~cm}$ in thickness) alternate with marls. The sandstone contains abundant quartz and mica, probably eroded from metamorphic rocks in the source area (metaschist and quartzite) and minor amounts of calcite grains from marbles, as well as common plant remains. Two sandstone subfacies occur: one that exhibits normal grading (Fig. 6A, B) and the other in which beds have a lower division with planar lamination and an upper division of very fineto fine-grained sandstone with hummocky and swaly cross-stratification (Fig. 6C). Rarely, the sandstone beds are over $1 \mathrm{~m}$ thick, dominated by hummocky and swaly cross-stratification (Fig. 6D) and with common soft-sediment deformation structures such as convolute lamination and pillow structures (Fig. 6E).

Interpretation.-The marl interval is interpreted to have formed in an area of mainly pelagic sedimentation, as deduced from the predominance of marls rich in planktonic foraminifera. Both the homogeneous nature of the marls and the bioturbation suggest oxygenated bottom conditions, as would be expected in a shallow marine environment, suitable to the development of burrowing macrofauna (Skolithos ichnofacies) and typical of an unstratified water column with frequent mixing of surface and bottom waters. The abundance of the planktonic foraminifer species G. bulloides, together with neogloboquadrinids, indicates cold-eutrophic waters (e.g., Sierro et al. 1999). On the basis of the occurrence of the planktonic foraminifer species $G$. suterae, the basal sediments were deposited around 7.8 Ma (late Tortonian).

The thin sandy levels intercalated in the marls are interpreted to correspond to episodic supply of siliciclastic sediment from the source area (Sierra Nevada metamorphic rocks). The normally graded beds are 


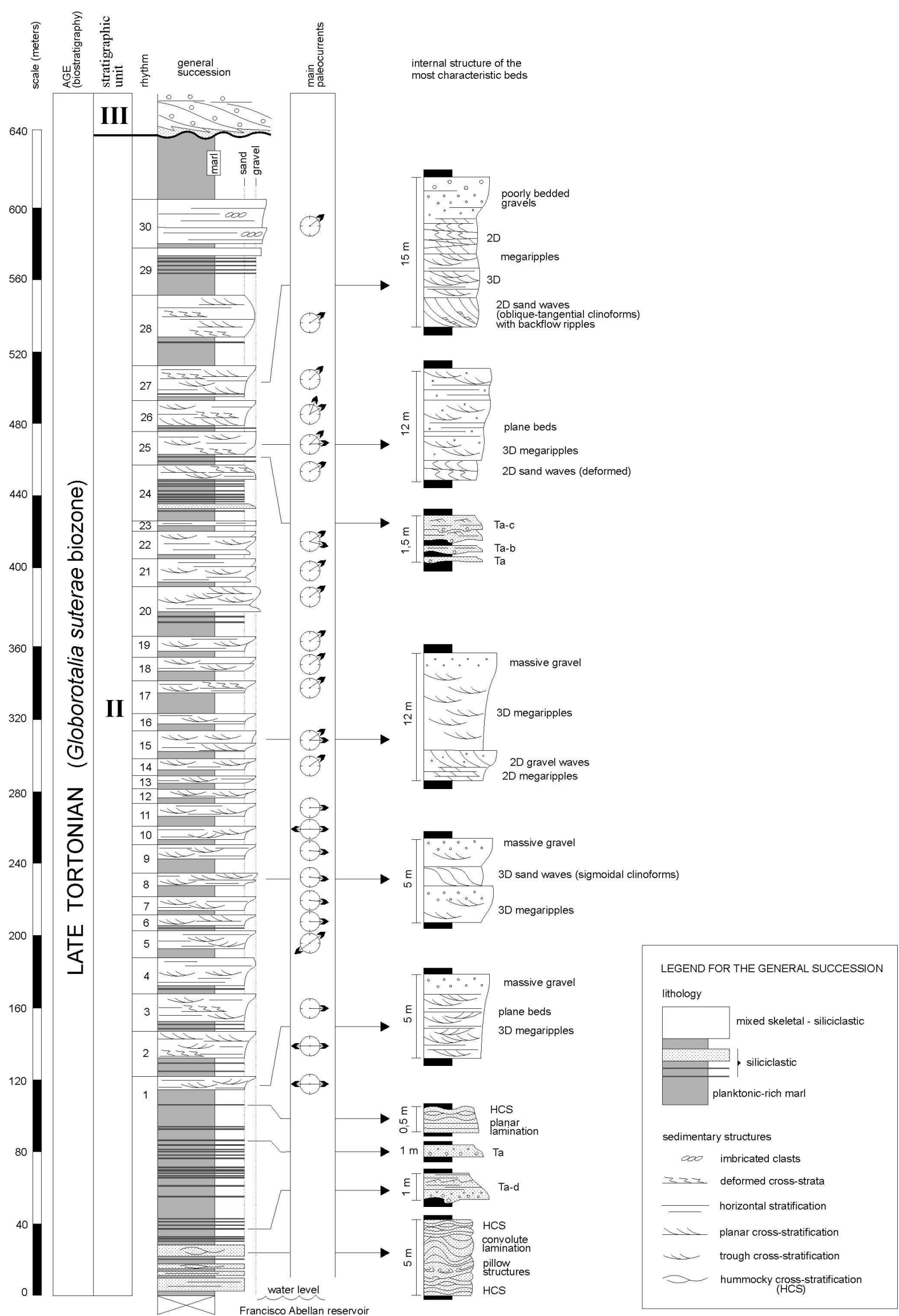



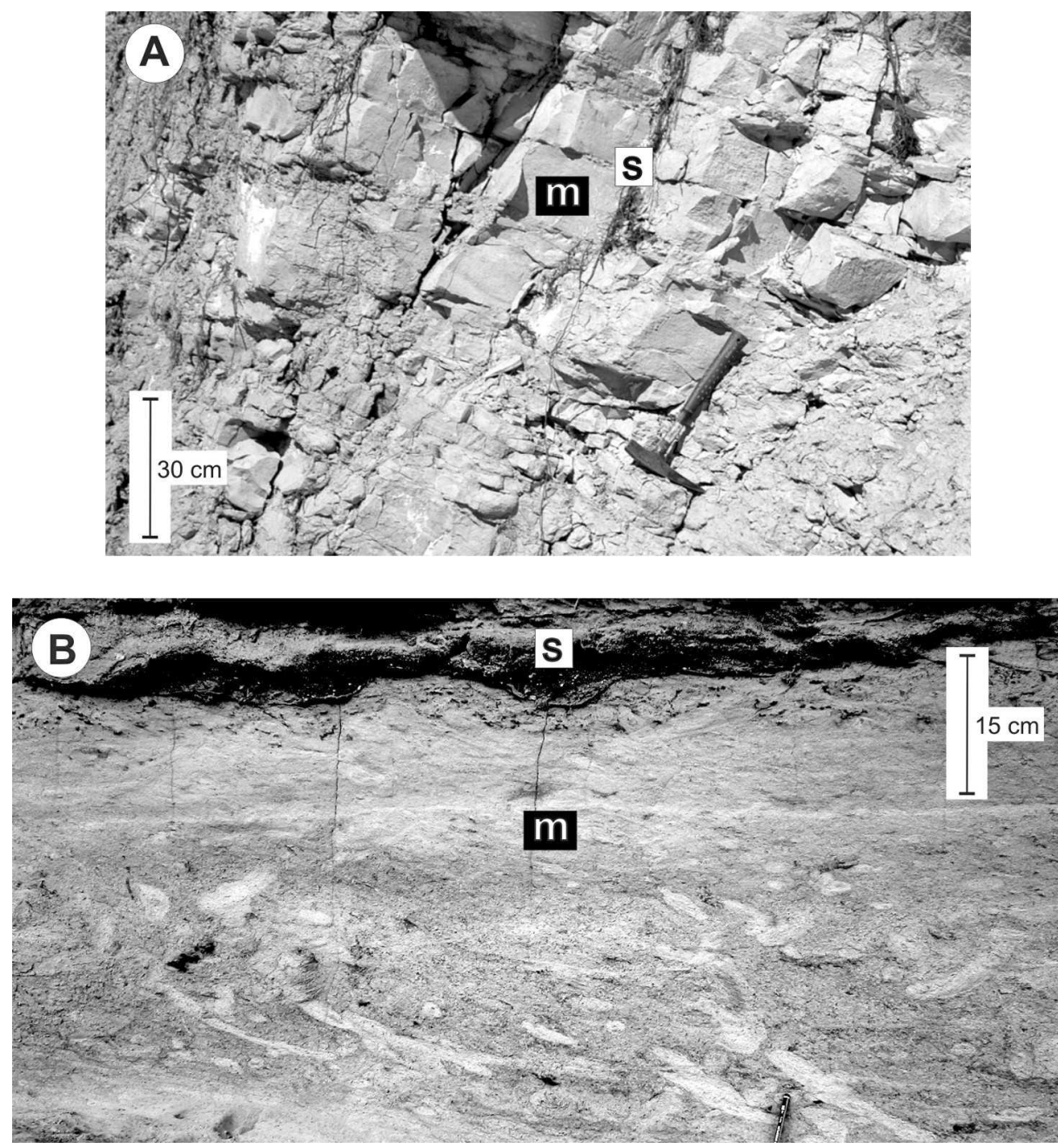

FIG. 5.- Marl interval of the rhythmites. A) Structureless marl (m) with thin siliciclastic sandstone layers(s). B) Bioturbation produced by burrowing organisms. interpreted to be typical incomplete Bouma sequences of types Ta, Ta-b, and $\mathrm{Ta}-\mathrm{c}$, deposited by turbidite flows. Abundant organic material such as plants indicates that the turbidity originated from river flood discharges and not from slopes, as suggested by the model of Postma (2001). On the basis of the lower division with planar lamination and an upper division of very fine- to fine-grained sandstone with hummocky and swaly cross-stratification suggestive of tempestites (e.g., Walker 1979; Cheel 1991; and Brenchley et al. 1993) other beds can be attributed to storm ebb surges. The regular presence of hummocky cross-stratification indicates that these tempestites were deposited below fair-weather wavebase and above storm wave-base by stormebb surges (see similar models in Walker 1979; Cheel 1991; and Brenchley et al. 1993). The soft-sediment deformation structures associated with the tempestites are interpreted to be due to the loading effect of waves during the deposition of storm beds, similar to the model proposed by Molina et al. (1998) and Alfaro et al. (2002).

Mixed Siliciclastic-Skeletal Sandstone and Conglomerates Facies Association.-This interval includes sheetlike bodies, hundreds to thousands of meters in lateral extent, ranging in thickness from 3 to
20 meters, that represent between 40 and $70 \%$ of the total thickness of each rhythmite. The lithofacies is composed of skeletal and siliciclastic grains in subequal proportions. Skeletal components range in size from $0.5 \mathrm{~mm}$ to over $2 \mathrm{~cm}$ and include coralline algae (Figs. 7A, 8A), bivalves (Fig. 7B), bryozoans (Fig. 7C), benthic foraminifera, echinoids, and brachiopods. Volumetrically, coralline algae are the most important phototrophs. Skeletal grains usually display a high degree of fragmentation and abrasion. Siliciclastics are dominantly subangular clasts, poorly sorted fine sand to pebble in size, dominated by quartz, feldspar, and lithic clasts from metamorphic rocks. A common feature of most of the mixed intervals is an upward increase in siliciclastic grain size, forming inversely graded beds.

Predominant structures are tabular cross-stratification (Fig. 8D, E) that occurs in sets $0.5-4 \mathrm{~m}$ in height, and trough cross-stratification (Fig. 8C) that forms sets $5 \mathrm{~cm}$ to $0.5 \mathrm{~m}$ in height, although local occurrences of planar lamination and massive intervals occur. Paleocurrents include similar patterns throughout the succession, consistent with unidirectional flow oriented $\mathrm{E}$ and $\mathrm{N} 50^{\circ} \mathrm{E}$. The sedimentary structures of the mixed interval follow a similar pattern in all the packages or rhythmites of the succession. Bioturbation is a common feature at the tops of the cross-stratified beds.

$\leftarrow$

FIG. 4.-Stratigraphic log of the succession showing the 30 rhythmites of Unit II, overlain by the allostratigraphic Unit III. 

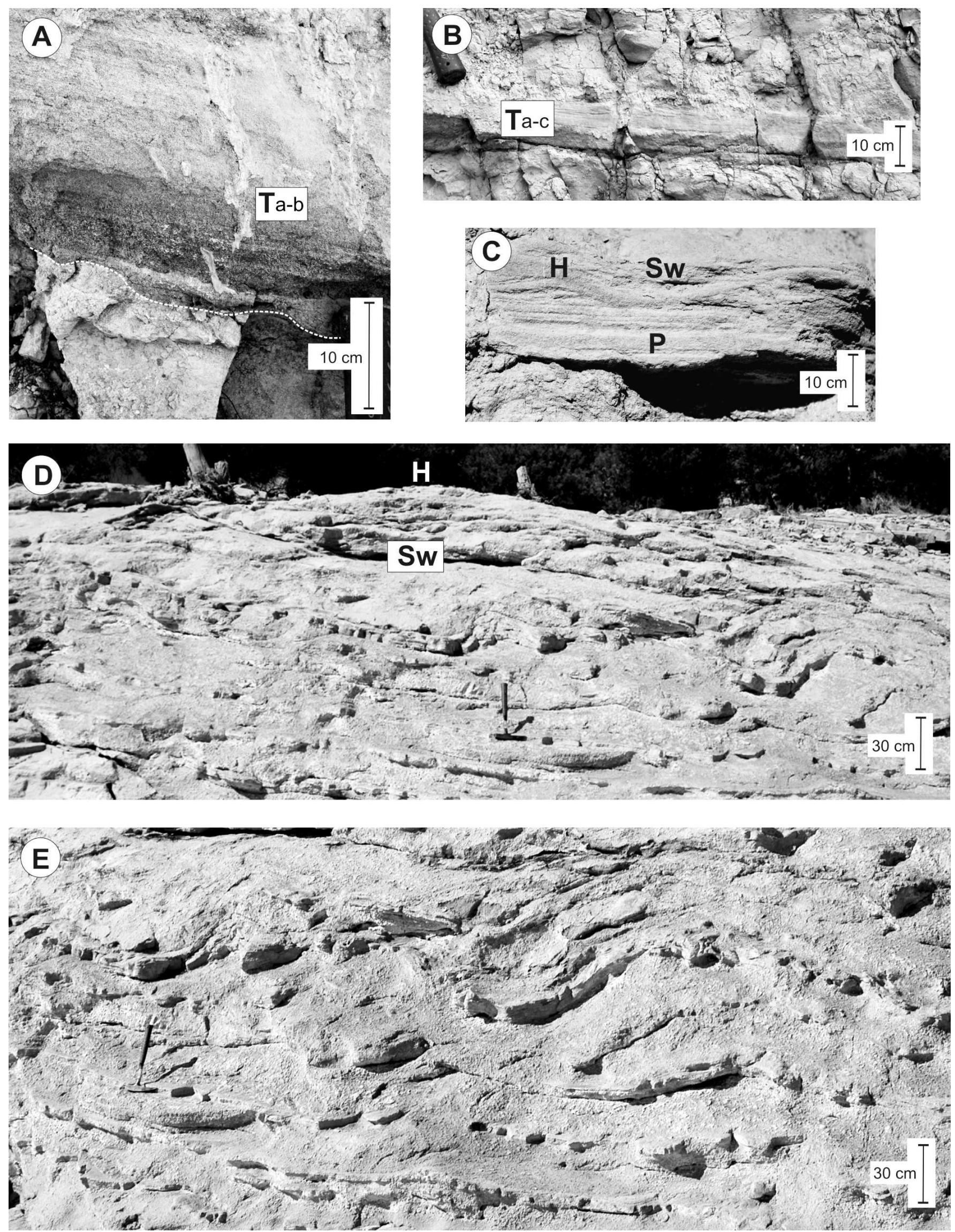

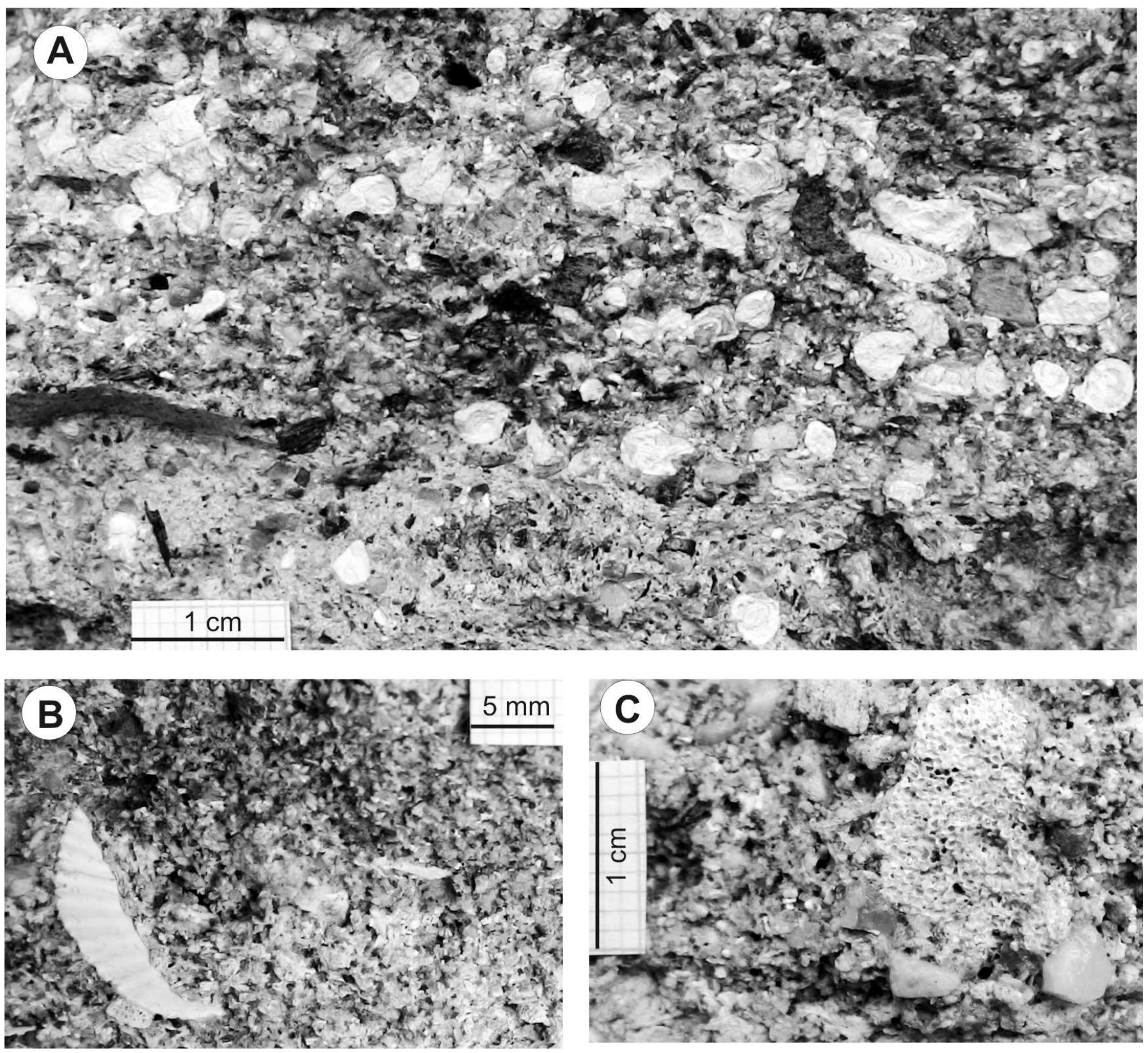

FIG. 7.-Biofacies of the mixed siliciclastic-skeletal interval, represented by a rhodalgal-bryomol association. A) Accumulation of coralline algae (rhodoliths) in coarse sandstone composed of metamorphic grains. B) Bivalve, identified as a pectinid. C) Scarce bryozoans among quartz grains.

The upper part of the cross-strata sets in some of the packages (Fig. 4) includes evidence for soft-sediment deformation, which always occurs below reactivation surfaces. In the thin tabular cross-strata $(15 \mathrm{~cm}$ in height), deformations comprise recumbent folds (Fig. 9A). In the sets of thick, concave-up cross-strata (1-3 m high), deformation consists of vergent folds, some with internal slides (Fig. 9B, C). Fold axial surfaces strike $\mathrm{N} 140^{\circ} \mathrm{E}$, and folds verge in the direction that cross-strata laminae dip.
Interpretation.-The biogenic components forming the mixed interval constitute a foramol-type association (rhodalgal-bryomol) typical of present-day temperate environments (sensu Lees and Buller 1972). The mixed interval has a rhodalgal biogenic association indicating a water depth of less than $100 \mathrm{~m}$ (Brandano et al. 2005). Late Tortonian rhodolite beds and branching red algae have been documented in outcrops $50 \mathrm{~km}$ from the study area (Braga and Martín 1988; García-García et al. 2006a, 2006b). They have been reported in different shallow-marine contexts,

FIG. 6.-Siliciclastic sandstones intercalated in the marl intervals. A) Ta-b Bouma sequence with erosional base, normal grading, and parallel lamination. B) Ta-c Bouma sequence characterized by a lower division with normal grading, an intermediate division with parallel lamination, and an upper division with current ripples. C) Thin bed showing a lower division with planar lamination and an upper division with hummocky $(\mathrm{H})$ and swaly (Sw) cross-stratification. D) Thick bed with large-scale swaly $(\mathrm{Sw})$ and hummocky $(\mathrm{H})$ cross-stratification. E) Soft-sediment deformation structures (convolute lamination). 

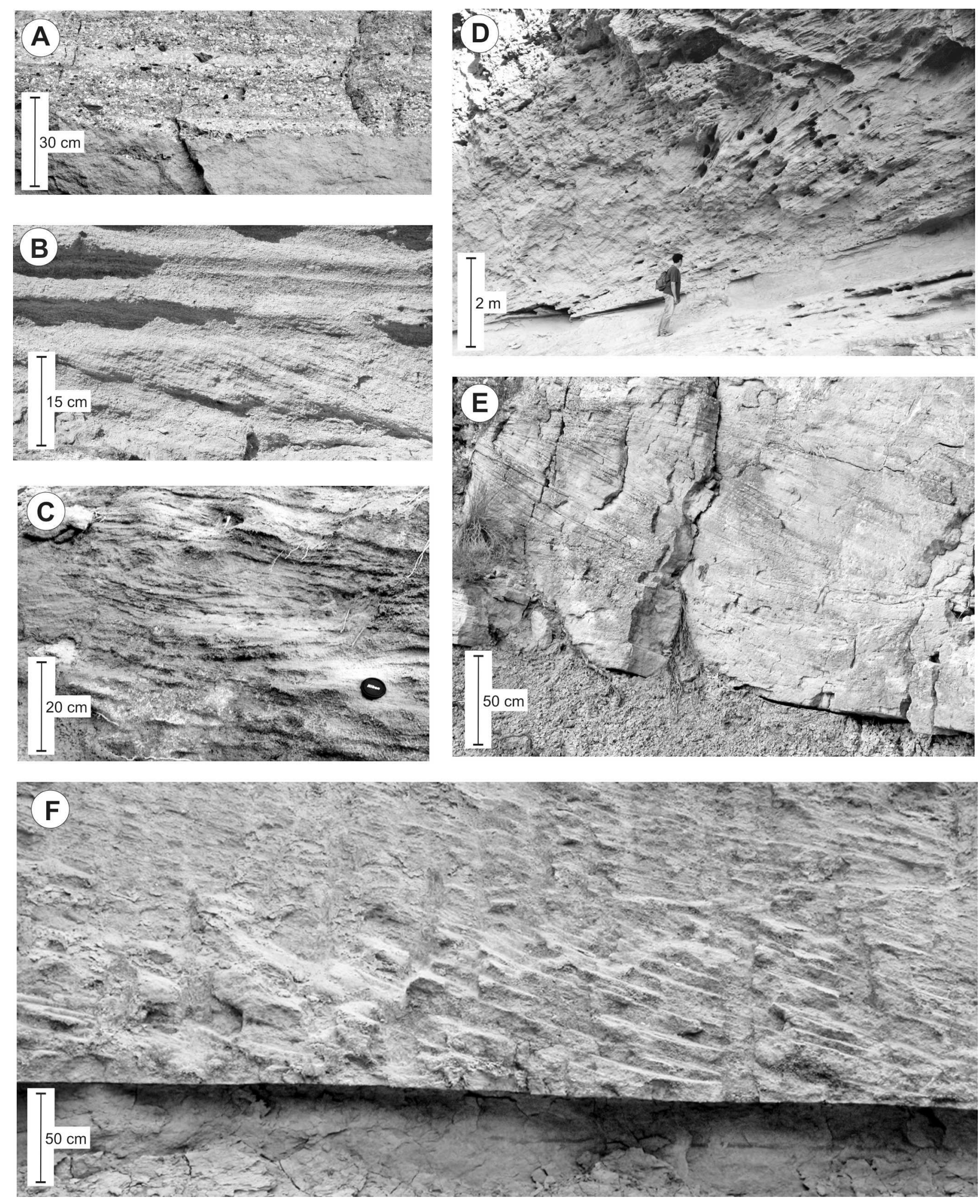

FIG. 8.- Mixed siliciclastic-skeletal interval of the rhythmites. A) Coralline algae (rhodoliths) in plane layers. B) Planar lamination (upper part) and tabular crosslamination arising from the migration of 2D megaripples (lower part). C) Gentle trough cross-stratification produced by the displacement of 3D megaripples. D) Large- 

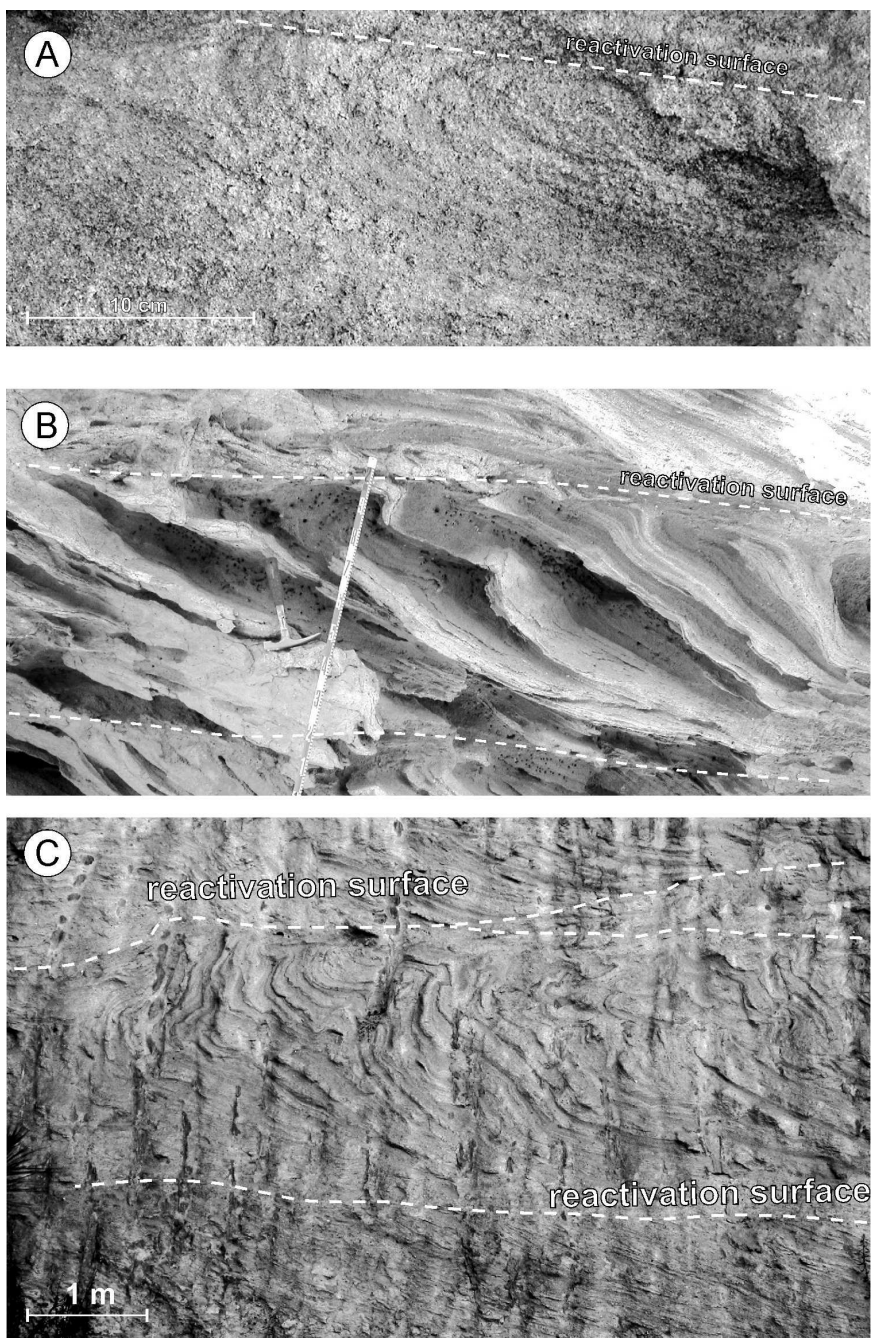

FIG. 9.- Geometry of the deformed cross-strata in the mixed siliciclasticskeletal interval. A) Recumbent folds in sets of small-scale tabular crosslamination (megaripples). B) Slides and C) vergent folds in large- to mediumscale, concave-upward cross-strata (sand dunes). Note that, in all cases, the deformed cross-strata occur below the reactivation surfaces and were produced by phases of high-energy tractive flows.

including patch reefs, coastal platforms, talus slopes (deepest at 35-40 m) (Braga and Martín 1988), and shoal-water- (García-García et al. 2006a) and Gilbert-type deltas at 10-20 m deep (García-García et al. 2006b). On the basis of their fragmentation, skeletal grains are interpreted as parautochthonous to allochthonous. The presence of bedforms suggestive of large-scale (2D and 3D) sandwaves and small-scale (2D and 3D) megaripples suggests the activity of strong currents capable of transporting bioclastic sandstone and pebble-size siliciclastic sediment. The decrease in bedform height from the bottom to the top of the interval is interpreted as a decrease in current energy (illustrated in packages 25 and 27 of the column in Fig. 4). Paleocurrents, mainly oriented $\mathrm{N} 90^{\circ} \mathrm{E}$ and $\mathrm{N} 50^{\circ} \mathrm{E}$, indicate sediment transport from the margin towards the interior of the shelf (note in Figs. 1B and 2A how these paleocurrents are directed from the basement toward the center of Guadix Basin). On the basis of the paleobathymetry assigned to the coralline algae documented in nearby deposits, the coralline algae factory in this succession is interpreted to represent a paleobathymetric range of 10 to $40 \mathrm{~m}$ deep. Basinward-migrating sandwaves interpreted from the cross-stratified beds suggest that the mixed interval is the result of deposition at depths range of 10 to $40 \mathrm{~m}$ and relocation farther down-ramp controlled by the efficiency of basinward currents driving the migration of the sand dunes and megaripples.

In all these cases, the deformed strata are oriented in the direction of the current generating the bedform. The deformed strata always occur below sandwave-scale cross strata and the lateral extension is restricted to a few meters. These structures are not restricted to single stratigraphic intervals that are correlatable over large areas, suggesting that they are not deformation structures with seismic events as originally proposed by Sims (1975). The deformed cross-strata are likely the result of an increase in flow regime during bedform migration. Applying to our examples the models proposed by Leeder (1987), Alfaro et al. (2000), and Roe and Hermansen (2005), high-velocity flows produce three effects (Fig. 9): (1) shear stress capable of liquefying the sediment; (2) drag in the direction of the current, thereby controlling the vergence of the deformed laminae; and (3) erosion of the upper part of the bedform, producing reactivation surfaces. The presence of deformed cross-strata indicates high-flow regimes.

\section{Sediment Dispersal}

The two intervals comprising these rhythmites reflect different hydrodynamic conditions as well. The homogeneous marls rich in planktonic organisms are characteristic of pelagic sedimentation. Terrigenous supply was sporadic, by means of turbidity flows and storm ebb surges. In contrast, the mixed siliciclastic-skeletal sediments represent high-energy conditions on the shelf. Skeletal grains are reworked by waves and currents, in contrast to the marl, where biotic components (planktonic foraminifera) are deposited from suspension settling. The migration of bedforms (sand dunes and megaripples) comprising coarse sediments implies the action of strong currents. The presence of deformed cross-strata indicates high-flow regimes, since such structures are typical of confined currents such as river channels (Roe and Hermansen 2005). These persistently basinward-directed currents dispersed sediment from the discharge zones towards the inner shelf, forming sheetlike bodies hundreds of meters wide. The origin of such currents is a difficult aspect to shed light on because various hydrodynamic agents (such as tides, waves, and storms) can move sediment by tractive flow in shallow marine environments. Tidal currents are effective in tidal channels, which record persistent periodic flow reversal (ebb and flood). In their sedimentary structures, these strata include no evidence of periodic flow reversal. Instead, the predominant sedimentary structures here are tabular crossstratification, representing unidirectionally migrating bedforms. The Mediterranean region has remained microtidal at least since the early Miocene, when its connection to the Indian Ocean was lost (Pedley and Carannante 2006). Waves generate both longshore currents and landward tractive flows (Stokes drift). In this particular case, paleocurrents, mainly oriented $\mathrm{N} 90^{\circ} \mathrm{E}$ and $\mathrm{N} 50^{\circ} \mathrm{E}$, indicate sediment transport from the margin towards the interior of the shelf (paleocurrents are directed from the basement high toward the center of Guadix Basin; Fig. 2A).

Ubiquitous hummocky cross-stratification and cross-bedding, lack of recognizable traces of tidal action, and rhythmic pattern of sedimentation, with evidence of event deposition followed by resumption of

$\leftarrow$

scale (5 m high), concave-upward cross-stratification associated with sandwave movement. E) Medium-scale cross-stratification (1 m high) formed by sigmoidal laminae. F) Sharp surface at the base of a cross-strata set, concave upward laminae, overlying the marl interval. 


\section{MARLY INTERVAL, dry - cool climate}

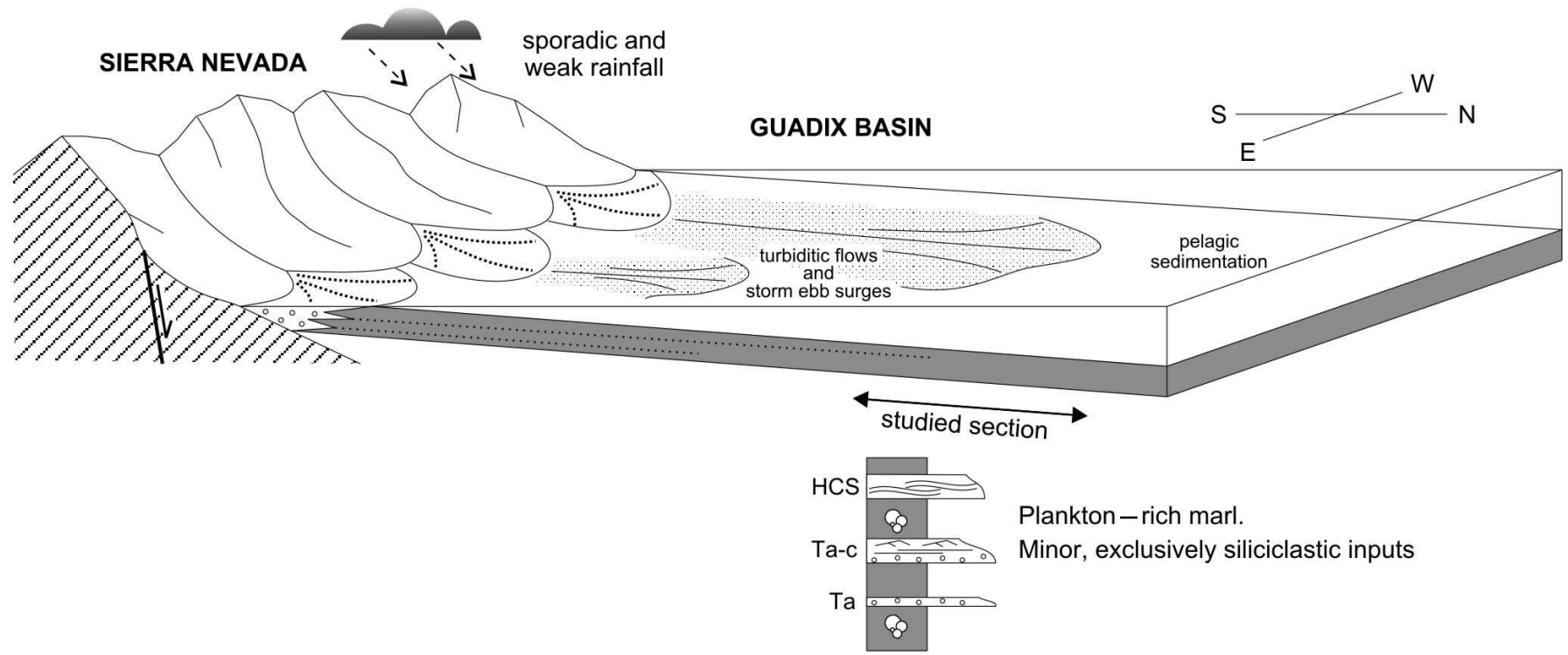

MIXED SILICICLASTIC - SKELETAL INTERVAL, wet - temperate climate

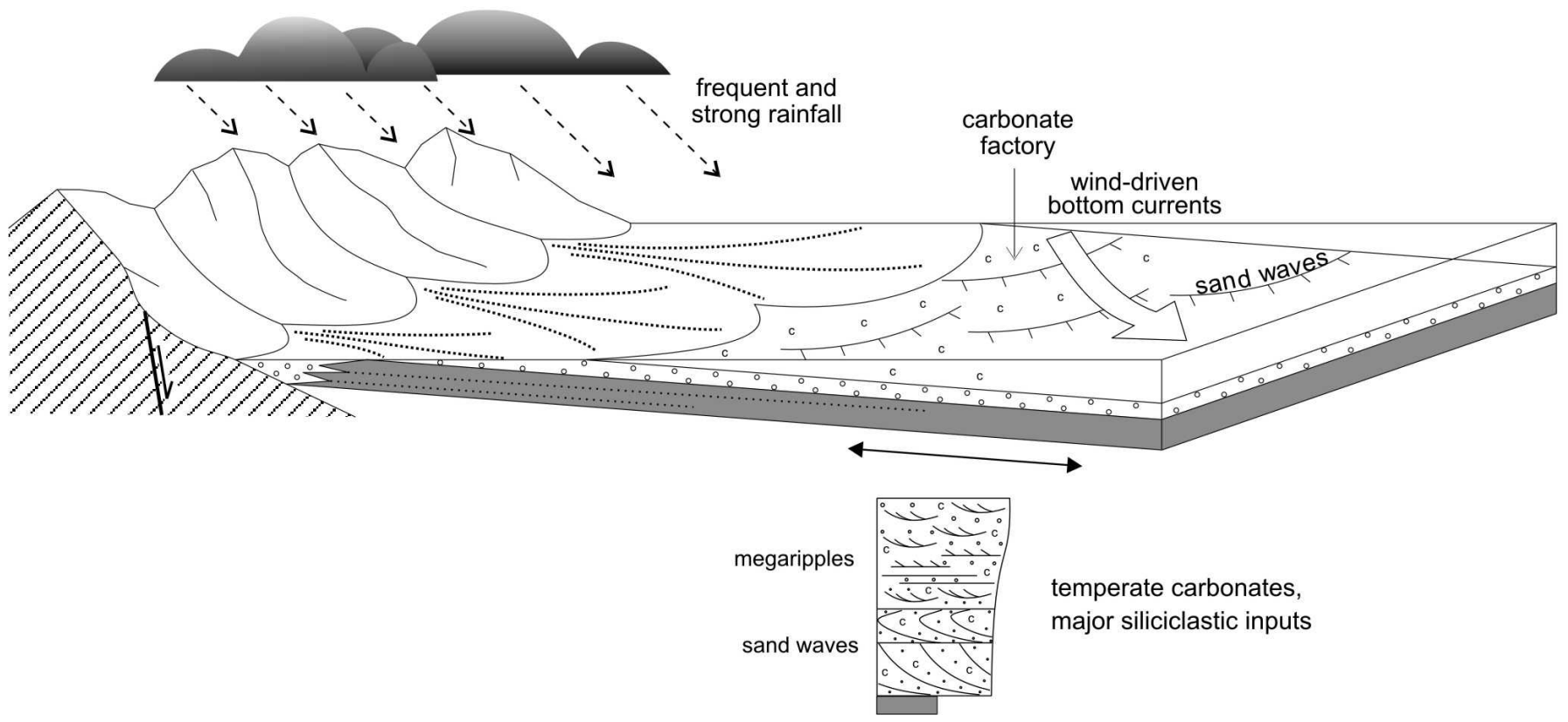

FIG. 10.-Rhythmicity model for the shallow-marine shelf in relation to climatic changes. A) During dry-cool episodes, the shelf is starved, and pelagic sedimentation dominates (plankton-rich marls); the only sediment supply is siliciclastic, produced by sporadic turbidity flows and storm ebb surges. B) During wet-temperate episodes, the shelf is subject to intense siliciclastic supply due to the increase in activity of the feeder systems. Simultaneously, typical cool-water carbonate factories arise. Both the siliciclastic and the skeletal components are dispersed towards the basin by wind-driven, storm-generated bottom currents, thereby causing the migration of large-scale bedforms (sand dunes). 
bioturbation, indicate a storm-dominated microtidal setting as responsible for the dispersal of coarse sediment on the shallow marine shelf. The importance of the physical action of waves and currents during storms affecting biocalcarenite bodies was stressed by Nelson et al. (1988) and reported in other Mediterranean cool-water ramps (Massari and Chiocci 2006). Storms produce intense winds caused by the steep pressure gradient associated with atmospheric depressions. Storm winds produce friction on the water surface that translates into Ekman currents (see Allen 1997 for more details). For a given water depth, these currents vary in flow regime as a function of the intensity of the generating wind. The size differences in the sedimentary structures forming the beds of mixed siliciclastic-skeletal sediments (from large sand waves to megaripples), in addition to the existence of deformed cross-strata, indicate fluctuating hydrodynamic conditions. This fluctuation is in agreement with the energy variations over the course of a storm, and have been interpreted on other temperate carbonate shelves (Caron et al. 2004; Brandano et al. 2005).

The persistence of the wind-driven, storm-generated currents in a dominant direction indicates that the entrance trajectory of squalls on the margin of the Guadix Basin remained constant over time or that this one direction was the effective only due to the combination of deeper water and direction of approach.

\section{SIGNIFICANCE OF THE RHYTHMICITY}

\section{Temporal Range}

The 30 rhythmites identified in the succession belong to Unit II of the marine sedimentary infill of the Guadix Basin. The base of Unit II coincides with the first occurrence of Globorotalia suterae (Soria 1993, 1994), dated at 7.8 Ma (Lourens et al. 2004). The upper boundary of Unit II corresponds to a rapid fall in sea level that produced the deposition of the last marine unit (Unit III) filling the Guadix Basin (Soria et al. 1999, 2000). Unit III represents a very short time interval during the latest Tortonian (foraminifers association characterized by Globorotalia suterae, without Globorotalia conomiozea-Globorotalia mediterranea). The rodent species Ruscinomis schaubi and Occitanomys adroveri, both characteristic of the late Turolian, or MN12, zone (Soria and Ruiz Bustos 1992) were identified at the base of the first continental deposits of the basin (Unit IV). This association is identical to that found at the base of the continental infill in the neighboring Granada Basin, whose age has been established as 7.2 Ma (Rodríguez-Fernández and Sanz de Galdeano 2006).

Unit II was deposited at most in $600 \mathrm{ka}$ from the base of Unit II (7.8 $\mathrm{Ma})$ to the base of Unit IV (7.2 Ma). Accordingly, the average recurrence interval of each of the 30 rhythmites is $20 \mathrm{ka}$. This frequency is consistent with the duration of precession orbital cycles, which have frequencies of $19 \mathrm{ka}$ and $23 \mathrm{ka}$ (Tuenter 2004). Read (1998) noted that carbonate ramps formed under icehouse conditions are characterized by unconformitybounded sequences linked to Milankovitch climatic changes. Climatic signatures documented in deep-marine deposits from the eastern Mediterranean (Postma and Drinia 1993; Postma et al. 1993) point to precession-punctuated variation in discharges in the late Miocene.

\section{Climate vs. Sea-Level Fluctuations}

Several factors could influence the deposition of these rhythmites, including sea-level change or climate change. An interpretation that they were driven by sea-level change would suggest that the two parts of each rhythmite were deposited at depths sufficiently different to account for the lithological differences. The interpretations above suggest, however, that both the marly and the mixed intervals were deposited in a shallow marine setting. In a sea-level-change model, the alternation of mixed and marly intervals mostly would represent the effect of lateral facies migration across the shelf in response to sea-level fluctuations. In a conceptual model of a cool-water carbonate ramp, on the basis of the lithofacies and biofacies, the mixed interval represents the sedimentation in an inner-ramp setting and the marly interval represents the sedimentation in a mid or outer ramp above storm wave base. Inverse grading of mixed-interval deposits is consistent with a model of pulses of prograding shelf representing inner ramp calcarenites alternating with mid- to outer-ramp marls. The mixed interval would have formed mainly during falling sea level, as reported from Pliocene-Quaternary cool-water carbonate wedges that typically alternate with mudstone units (Massari and Chiocci 2006). But, which is the factor forcing the sea-level fluctuations in that sedimentary model? On the basis of the biofacies, marl was deposited in cold-eutrophic waters and calcarenite was deposited in cool (but warmer) waters. A glacio-eustatic forcing does not appear to be appropriate, because it would be expected that the marl was deposited during falling or lowstand stages (colder stages) and calcarenite was deposited during rising or highstand stages (warmer stages). Relative falls in sea level and shelf progradation could be a response to local tectonic uplift pulses as an alternative to glacio-eustasy. In addition to lack of compressive tectonic evidences during deposition of the succession, this depositional model controlled by compressional tectonics explains neither the preservation of marls nor the aggradational stratal pattern of 30 rhythmites making up the 650 -m-thick succession.

A second possibility is that the lithologic variability is due to changes in climate with no substantial changes in depth. In such a model, climate change could influence both siliciclastic sediment supply and biota, including skeletal association and carbonate productivity and sediment dispersal (Fig. 10). In this case, the marly intervals could correspond to episodes of a dry-cold climate, as reflected in: (1) a scarcity of siliciclastic supply due to a decrease in precipitation and the consequent inactivity of the feeding systems in the source area; (2) the siliciclastic composition of the sediments, with no biogenic carbonates from coastal areas because the carbonate-factory production rates would be expected to decrease as the waters became too cold to support carbonate-secreting organisms (seawater temperature in addition to nutrient availability and light limit the diversity of skeleton-secreting organisms able to colonize substrates; Pomar 2001); and (3) the association of planktonic organisms dominated by species typical of cold eutrophic waters. In contrast, the mixed siliciclastic-skeletal interval could correspond to sedimentation during a temperate-wet climate stage, as suggested by: (1) supply of coarse sediments produced by intense precipitation in the source area; and (2) carbonate factories of a rhodalgal-bryomol type, characteristic of temperate waters. Vigorous atmospheric and marine circulation can play a major critical role in enhancing the efficiency of the carbonate factory (Schlager 2004). Wind intensification and enhanced turbulent mixing in the water column may lead to nutrient renewal and in turn may lead to greater efficiency of the carbonate factory (Massari and Chiocci 2006). Oceanic flood (Wheatcroft 2000) is a climatically controlled model which would explain flood events in the drainage basins (supply of coarse sediments during mixed interval) and simultaneous high-energy conditions on the shelf (sandwave migration). Oceanic flood occurs over short time periods on small rivers, and the key aspect of the oceanic flood is that the river-ocean system responds to the same storm system (Wheatcroft 2000). Poor maturity of the mixed-interval deposits (textural immaturity reflected by angular grains, poor sorting, and compositional immaturity represented by predominant rock fragments and plants) is consistent with the idea of a short-time sedimentary cycle for the metamorphic grains. Abundant organic material such as plants indicates the turbidites originated from river flood discharges (Postma 2001). In small drainage basins, the storms cause important changes in runoff with instantaneous increase in both competence and carrying capacity of the streams, resulting in river floods with important increases in the total 
sediment supply and grain size delivered onto the clastic marine systems (Postma 2001).

The rhythmic succession represents a unique record of precessioncontrolled climatic cycles for the late Miocene in this region, which most commonly include homogeneous marl-sapropel rhythmic successions (Hilgen et al. 1995; Nijenhuis 1999; Sierro et al. 1999; Vázquez et al. 2000; Krijgsman et al. 2001). It is assumed in these works that the homogeneous marl interval records dry-climate conditions, corresponding to maximum precession and minimum insolation. In contrast, the sapropels record humid conditions, coinciding with minimum precession and maximum insolation.

In this succession, the lack of sapropels may reflect the location of the study succession in proximal areas of the shallow marine platform, areas that would be strongly influenced by terrigenous supply from the source area during wet-climate stages. Similarly, at a broader, Mediterraneanwide scale, wet-climate episodes are characterized by enhanced fluvial runoff, largely due to the influence of Atlantic-born depressions (Nijenhuis 1999). Furthermore, in other areas, this wet-climate phase was characterized by the accumulation of turbidite sequences fed by bedload-type rivers (Schenau et al. 1999).

\section{Tectonic Subsidence and Accommodation}

It is widely accepted that sediment supply and accommodation space are the dominant controls on stratigraphic packaging (e.g., Schlager 1993). Sea-level rise or subsidence controls the creation of accommodation space. During the period recorded in the study succession (latest Tortonian), the eustatic rise recorded on the global curve is less than 30 meters (Hardenbol et al. 1998), suggesting that subsidence was the major factor in creating accommodation space. The most characteristic feature of the studied succession is the regular repetition of the lithofacies, biofacies, and sedimentary structures through the rhythmite succession. This consistency implies that the sediments through the succession were deposited at similar water depths and hydrodynamic regime. To accomplish this, the ratio of tectonic subsidence to sediment supply must have been roughly constant such that creation of accommodation space was compensated for by sedimentation. The subsidence history of the basin has been reported by Soria et al. (1998) with geohistorical diagrams which show that a period of strong to weak $(0.48$ to $0.07 \mathrm{~mm} / \mathrm{yr})$ subsidence occurred during the late Tortonian when rhythmic succession developed. Fault growth controlled the subsidence and the sedimentary evolution of the southern margin of the basin, which is revealed as an active tectonically extensional margin during the late Tortonian (GarcíaGarcía et al. 2006a). We propose that the stratigraphic packaging of the studied succession is a result of climatically controlled sediment supply (rhythmite-scale control) and tectonically controlled creation of accommodation space (succession-scale control). The tectonic subsidence would explain the aggradational stratal pattern of the complete succession, the lack of emersion features with high sedimentation rate in shallow marine waters (a succession $640 \mathrm{~m}$ thick was deposited at most in $600 \mathrm{ka}$ ) and the fine sediment (marl interval) preservation. Papers referenced document the tectonic control close to the study area.

\section{CONCLUSIONS}

The shallow-marine Tortonian rhythmic succession from the Guadix Basin includes the stratigraphic record of cyclical climate changes. These changes controlled the type of sedimentation, producing stacked rhythmites made of two intervals with contrasting lithologies, reflected in differences in biogenic production and mode of transport and sedimentation. In each rhythmite, the mixed siliciclastic-carbonate interval is interpreted to record wet temperate conditions, characterized by: (1) heavy discharges of coarse-grained siliciclastic sediments; (2) rhodalgal-bryomol carbonate factories; and (3) high-energy hydrodynamic regimes with intense persistent currents flowing towards the inner shelf. In contrast, the homogeneous marl interval in each rhythmite is interpreted to record cold, dry conditions typified by: (1) mud deposition by suspension settling; (2) planktonic foraminifer associations typical of cold waters; and (3) low-energy hydrodynamic regimes with sporadic entry of sand via turbidity flows and storm ebb surges.

On the basis of the biostratigraphy, the time interval for this rhythmic succession ranges from 7.8 Ma to 7.2 Ma (late Miocene). The 30 rhythmites present indicate a climatic cyclicity of $20 \mathrm{ka}$, a frequency that fits wells with precession-related climatic oscillations. The similarity in water depth for the 30 rhythmites from the bottom to the top of the succession (640 meters thick) appears to have required continuous creation of accommodation space by tectonic subsidence originated by the activity of the extensional faults on the basin margin.

\section{ACKNOWLEDGMENTS}

This research was supported by projects CGL2005-06224/BTE and CGL2007-65832/BTE financed by the Spanish Ministry of Education and Science (MEC), the European Found of Regional Development (FEDER), and Research Group RNM-163 and RNM-200 of the Junta de Andalucía. Christine Laurin is thanked for the English version of the text. The paper has benefited greatly by the constructive comments of reviewers Lynn Soreghan and W. Lynn Watney, Associate Editor Mike Grammer, and Editors Gene Rankey and Colin P. North.

\section{REFERENCES}

Agustí, J., Cabrera, L., Garcés, M., Krijgsman, W., Oms, O., and Parés, J.M., 2001, A calibrated mammal scale for the Neogene of Western Europe. State of the art: Earth-Science Reviews, v. 52, p. 247-260.

Alfaro, P., Estévez, A., Moretti, M., and Soria, J.M., 2000, Estructuras sedimentarias de deformación en el Mioceno superior-Cuaternario de la Cordillera Bética: Sociedad Geológica de España, Revista, v. 13, p. 79-89.

Alfaro, P., Delgado, J., Estévez, A., Molina, J.M., Moretti, M., and Soria, J.M., 2002, Liquefaction and fluidization structures in Messinian storm deposits (Bajo Segura Basin, Betic Cordillera, southern Spain): International Journal of Earth Sciences, v. 91, p. 505-513.

Allen, P.A., 1997. Earth Surface Processes: Oxford, U.K., Blackwell Science, 404 p.

Berggren, W.A., Kent, D.V., Swisher, C.C., and Aubry, M.P., 1995, A revised Cenozoic geochronology and chronostratigraphy, in Berggren, W.A., Kent, D.V., Aubry, M.P., and Hardenbol, J., eds., Geochronology, Time Scales and Global Stratigraphic Correlation: SEPM, Special Publication 54, p. 129-212.

Brachert, T.C., Betzler, C., Braga, J.C., and Martín, J.M., 1996, Record of climatic change in neritic carbonates: turnover in biogenic associations and depositional modes (late Miocene, southern Spain): Geologische Rundschau, v. 85, p. $327-337$.

Braga, J.C., AND Martin, J.M., 1988, Neogene coralline-algal growth-forms and their palaeoenvironments in the Almanzora river valley (Almería, SE Spain): Palaeogeography, Palaeoclimatology, Palaeoecology, v. 67, p. 285-303.

BRAGA, J.C., AND MARTIN, J.M., 1996, Geometries of reef advance in response to relative sea-level changes in a Messinian (uppermost Miocene) fringing reef (Cariatiz reef, Sorbas basin, SE Spain): Sedimentary Geology, v. 107, p. 61-81.

Brandano, M., Vannucci, G., Pomar, L., and Obrador, T., 2005, Rhodolith assemblages from the lower Tortonian carbonate ramp of Menorca (Spain): Environmental and paleoclimatic implications: Palaeogeography, Palaeoclimatology, Palaeoecology, v. 226, p. 307-323.

Brenchley, P.J., Pickerill, R.K., and Stromberg, S.G., 1993, The role of wave reworking on the architecture of storm sandstone facies, Bell Island Group (Lower Ordovician), eastern Newfoundland: Sedimentology, v. 40, p. 359-382.

Caron, V., Nelson, C.S., and Kamp, P.J.J., 2004, Contrasting carbonate depositional systems for Pliocene cool-water limestones cropping out in central Hawke's Bay, New Zealand: New Zealand Journal of Geology and Geophysics, v. 47, p. 697-717.

Cheel, R.J., 1991, Grain fabric in hummocky cross-stratified storm beds: genetic implications: Journal of Sedimentary Petrology, v. 61, p. 102-110.

Fernández, J., Soria, J.M., and Viseras, C., 1996, Stratigraphic architecture of the Neogene basins in the central sector of the Betic Cordillera (Spain): tectonic control and base level changes, in Friend, P.F., and Dabrio, C.J., eds., Tertiary Basins of Spain. The Stratigraphic Record of Crustal Kinematics: Cambridge, U.K., Cambridge University Press, p. 353-365.

García-García, F., Fernández, J., Viseras, C., and Soria, J.M., 2006a, Architecture and sedimentary facies evolution in a delta stack controlled by fault growth (Betic Cordillera, southern Spain, late Tortonian): Sedimentary Geology, v. 185, p. 79-92. 
García-Garcia, F., Fernández, J., Viseras, C., and Soria, J.M., 2006b, Highfrequency cyclicity in a vertical alternation of Gilbert-type deltas and carbonate bioconstructions in the late Tortonian, Tabernas Basin, Southern Spain: Sedimentary Geology, v. 192, p. 123-139.

HANSEN, K.S., 1999, Development of a prograding carbonate wedge during sea level fall: Lower Pleistocene of Rhodes, Greece: Sedimentology, v. 46, p. 559-576.

Hardenbol, J., Thierry, J., Farley, M.B., Jacquin, T., de Graciansky, P.C., de Vail, P., 1998, Mesozoic and Cenozoic sequence chronostratigraphic chart, in de Graciansky, P.C., Hardenbol, J., Jacquin, T., and Vail, P., eds., Mesozoic and Cenozoic Sequence Stratigraphy of European Basins: SEMP, Special Publication 60, p. 83-86.

Hilgen, F.J., Krijgsman, W., Langereis, C.G., Lourens, L.J., Santarelli, A., and Zachariasse, W.J., 1995, Extending the astronomical (polarity) time scale into the Miocene: Earth and Planetary Science Letters, v. 136, p. 495-510.

Iaccarino, S.M., And Premoli Silva, I., 2007, Practical manual of Neogene planktonic foraminifera, in Biolzi, M., Iaccarino, S.M., Turco, E., Checconi, A., and Rettori, R., eds., International School on Planktonic Foraminifera VI course: Neogene, Peruggia, Italy, $181 \mathrm{p}$.

Krijgsman, W., Fortuin, A.R., Hilgen, F.J., And Sierro, F.J., 2001, Astrochronology for the Messinian Sorbas basin (SE Spain) and orbital (precessional) forcing for evaporite cyclicity: Sedimentary Geology, v. 140, p. 43-60.

LEEDER, M., 1987, Sediment deformation structures and the palaeotectonic analysis of sedimentary basins, with case-study from the Carboniferous of northern England, in Jones, M.E., and Perston, R.M.F., eds., Deformation of Sediments and Sedimentary Rocks: Geological Society of London, Special Publication 29, p. 137-146.

LeEs, A., AND Buller, A.T., 1972, Modern temperature water and warm water shelf carbonate: Marine Geology, v. 13, p. 1767-1773.

Lourens, L.J., Hilgen, F.J., Laskar, J., Shackleton, N.J., and Wilson, D., 2004, The Neogene period, in Gradstein, F.M., Ogg, J.G., and Smith, A.S., eds., A Geologic Time Scale: Cambridge, U.K., Cambridge University Press, p. 409-440.

LuKasiK, J., AND James, N.P., 2006, Carbonate sedimentation, climate change and stratigraphic completeness on a Miocene cool-water epeiric ramp, Murray Basin, South Australia, in Pedley, H.M., and Carannante, G., eds., Cool-Water Carbonates; Depositional Systems and Palaeoenvironmental Controls: Geological Society of London, Special Publication 255, p. 217-244.

Massari, F., AND ChIOCCI, F., 2006, Biocalcarenite and mixed cool-water prograding bodies of the Mediterranean Pliocene and Pleistocene: architecture, depositional setting and forcing factors, in Pedley, H.M., and Carannante, G., eds., Cool-water Carbonates: Depositional Systems and Palaeoenvironmental Controls: Geological Society of London, Special Publication, v. 255, p. 95-120.

MichalziK, D., 1996, Lithofacies, diagenetic spectra and sedimentary cycles of Messinian (late Miocene) evaporites in SE Spain: Sedimentary Geology, v. 106, p. 203-222.

Molina, J.M., Alfaro, P., Moretti, M., and Soria, J.M., 1998, Soft-sediment deformation structures induced by cyclic stress of storm waves in tempestites (Miocene, Guadalquivir Basin, Spain): Terra Nova, v. 10, p. 145-150.

Nelson, C.S., Keane, S.L., and Head, P.S., 1988, Non-tropical carbonate deposits on the modern New Zealand shelf, in Nelson, C.S., ed., Non-tropical shelf carbonates: modern and ancient sediment: Sedimentary Geology, v. 60, p. 71-94.

NiJenhuis, I.A., 1999, Geochemistry of eastern Mediterranean sedimentary cycles: on the origin of Miocene to Pleistocene sapropels, laminites and diatomites [Ph.D. Thesis]: University of Utrecht: The Netherlands, $162 \mathrm{p}$.

Opdyke, N.D., Mein, P., Lindsay, E., Pérez-González, A., Moissenet, E., and Norton, V.L., 1997, Continental deposits, magnetostratigraphy and vertebrate paleontology, late Neogene of Eastern Spain: Palaeogeography, Palaeoclimatology, Palaeoecology, v. 133, p. 129-148.

Pedley, H.M., And Carannante, G., 2006, Cool-water carbonate ramps: a review, in Pedley, H.M., and Carannante, G., eds., Cool-Water Carbonates: Depositional Systems and Palaeoenvironmental Controls: Geological Society of London, Special Publication 255, p. 1-9.

Pomar, L., 2001, Types of carbonate platforms: a genetic approach: Basin Research, v. 13, p. $313-334$

Postma, G., 2001, Physical climate signatures in shallow- and deep-water deltas: Global and Planetary Change, v. 28, p. 93-106.

Postma, G., And Drinia, G., 1993, Architecture and sedimentary facies evolution of a marine, expanding outer-arc half-graben (Crete, late Miocene): Basin Research, v. 5, p. $103-124$.

Postma, G., Hilgen, F.G., and Zachariasse, W.J., 1993, Precession-punctuated growth of a late Miocene submarine-fan lobe on Gavdos (Greece): Terra Nova, v. 5, p. $103-124$.

READ, J.F., 1998, Phanerozoic carbonate ramps from greenhouse, transitional, and icehouse worlds: clues from field and modelling studies, in Wright, V.P., and Burchette, T.P., eds., Carbonate Ramps: Geological Society of London, Special Publication 149, p. 107-136.

Rodríguez Fernández, J., 1982, El Mioceno del sector central de las Cordilleras Béticas [Ph.D. Thesis]: University of Granada, Spain, 224 p.
Rodríguez Fernández, J., and Sanz de Galdeano, C., 2006, Late orogenic intramontane basin development: the Granada basin, Betics (southern Spain): Basin Research, v. 18, p. 85-102.

Roe, S.-L., and Hermansen, M., 2005, New aspects of deformed cross-strata in fluvial sandstones: Examples from Neoproterozoic formations in northern Norway: Sedimentary Geology, v. 186, p. 283-293.

Roep, T.B. Dabrio, C.J., Fortuin, A.R., and Polo, M.D., 1998, Late highstand patterns of shifting and stepping coastal barriers and washover-fans (late Messinian, Sorbas basin, S.E. Spain): Sedimentary Geology, v. 116, p. 27-56.

Ruiz Bustos, A., 1990, Biostratigraphy of the continental Neogene in the Betic Cordilleras:, IX Congress of the Regional Commitee on Neogene Stratigraphy: Barcelona, Spain, p. 301-302.

Sanz de Galdeano, C., And Vera, J.A., 1992, Stratigraphic record and palaeogeographical context of the Neogene basins in the Betic Cordillera, Spain: Basin Research, v. 4, p. 21-36

Schenau, S.J., Antonarakou, A., Hilgen, F.J., Lourens, L.J., Nijenhuis, I.A., Van Der Weijden, C., and Zachariasse, W.J., 1999, Organic-rich layers in the Metochia section (Gavdos, Greece): evidence for a single mechanism of sapropel formation during the past $10 \mathrm{My}$ : Marine Geology, v. 153, p. 117-135.

Schlager, W., 1993, Accommodation and supply-a dual control on stratigraphic sequences: Sedimentary Geology, v. 86, p. 111-136.

Schlager, W., 2004, Fractal nature of stratigraphic sequences: Geology, v. 32, p. 185-188.

SesÉ, C., 1989, Micromamíferos del Mioceno, Plioceno y Pleistoceno de la Cuenca de Guadix-Baza: Trabajos sobre el Neógeno y Cuaternario, v. 11, p. 185-213.

Sierro, F.J., Flores, J.A., Zamarreño, Y., Vazquez, A., Utrilla, R., Francés, G., Hilgen, F.J., and Krijgsman, W., 1999, Messinian pre-evaporite sapropels and precession-induced oscillation in western Mediterranean climate: Marine Geology, v. 153 , p. $137-149$.

Sims, J.D., 1975, Determining earthquake recurrence intervals from deformational structures in young lacustrine sediments: Tectonophysics, v. 29, p. 144-152.

Soria, J.M., 1993, La sedimentación neógena entre Sierra Arana y el río Guadiana Menor. Evolución desde un margen continental hasta una cuenca intramontañosa [Ph.D. Thesis]: University of Granada: Spain, 292 p.

SoRIA, J.M., 1994, Evolución sedimentaria y paleogeográfica durante el Mioceno Superior en el borde norte de la Cuenca de Guadix, Cordillera Bética central: Estudios Geológicos, v. 50, p. 59-69.

Soria, J.M., And Ruiz Bustos, A., 1992, Nuevos datos sobre el inicio de la sedimentación continental en la Cuenca de Guadix. Cordillera Bética: Geogaceta, v. 11, p. $92-94$.

Soria, J.M., Viseras, C., And Fernández, J., 1998, Late Miocene-Pleistocene tectonosedimentary evolution and subsidence history of the central Betic Cordillera (Spain): a case study in the Guadix intramontane basin: Geological Magazine, v. 135, p. $565-574$

Soria, J.M., Fernández, J., And Viseras, C., 1999, Late Miocene stratigraphy and palaeogeographic evolution of the intramontane Guadix Basin (Central Betic Cordillera, Spain): implications for an Atlantic-Mediterranean connection: Palaeogeography, Palaeoclimatology, Palaeoecology, v. 151, p. 255-266.

Soria, J.M., Fernández, J., AND Viseras, C., 2000, Sistemas de delta y plataforma en la Cuenca de Guadix (Mioceno superior, Cordillera Bética): El registro estratigráfico de regresiones forzada y normal: Geotemas, v. 1, p. 205-208.

Soria, J.M., Fernández, J., García, F., and Viseras, C., 2003, Correlative lowstand deltaic and shelf systems in the Guadix Basin (late Miocene, Betic Cordillera, Spain) the stratigraphic record of forced and normal regressions: Journal of Sedimentary Research, v. 73, p. 912-925.

Tesson, M., Posamentier, H.W., And Gensous, B., 2000, Stratigraphic organization of late Pleistocene deposits of the western part of the Golfe du Lion shelf (Languedoc shelf), western Mediterranean sea, using high-resolution seismic and core data: American Association of Petroleum Geologists, Bulletin, v. 84, p. 119-150.

TuEnter, E., 2004, Modeling orbital induced variations in circum-Mediterranean climate [Ph.D. Thesis]: University of Utrecht: The Netherlands, $151 \mathrm{p}$.

Vázquez, A., Utrilla, R., Zamarreño, Y., Sierro, F.J., Flores, J.A., Francés, G. and Barcena, M.A., 2000, Precession related sapropelites of the Messinian Sorbas basin (South Spain): Paleoenvironmental significance: Palaeogeography, Palaeoclimatology, Palaeoecology, v. 158, p. 353-370.

Vera, J.A., 1968, El Mioceno del borde SW de la Depresión de Guadix: Acta Geológica Hispánica, v. 5, p. 124-127.

Viseras, C., Soria, J.M., And Fernández, J., 2004, Cuencas neógenas postorogénicas de la Cordillera Bética, in Vera, J.A., ed., Geología de España: Sociedad Geológica de España-Instituto Geológico y Minero de España: Madrid, Spain, p. 576-581.

WALKER, R.G., 1979, Shallow marine sands, in Walker, R.G., ed., Facies Models: Geoscience Canada, Reprint Series 1, p. 75-89.

Wheatcroft, R.A., 2000, Oceanic flood sedimentation: a new perspective: Continental Shelf Research, v. 201, p. 2059-2066.

Received 15 November 2007; accepted 29 October 2008. 